\title{
TOWARDS STRENGTHS-BASED PLANNING STRATEGIES FOR RURAL LOCALITIES IN FINLAND
}

\author{
Emilia Rönkkö', Eeva Aarrevaara²
}

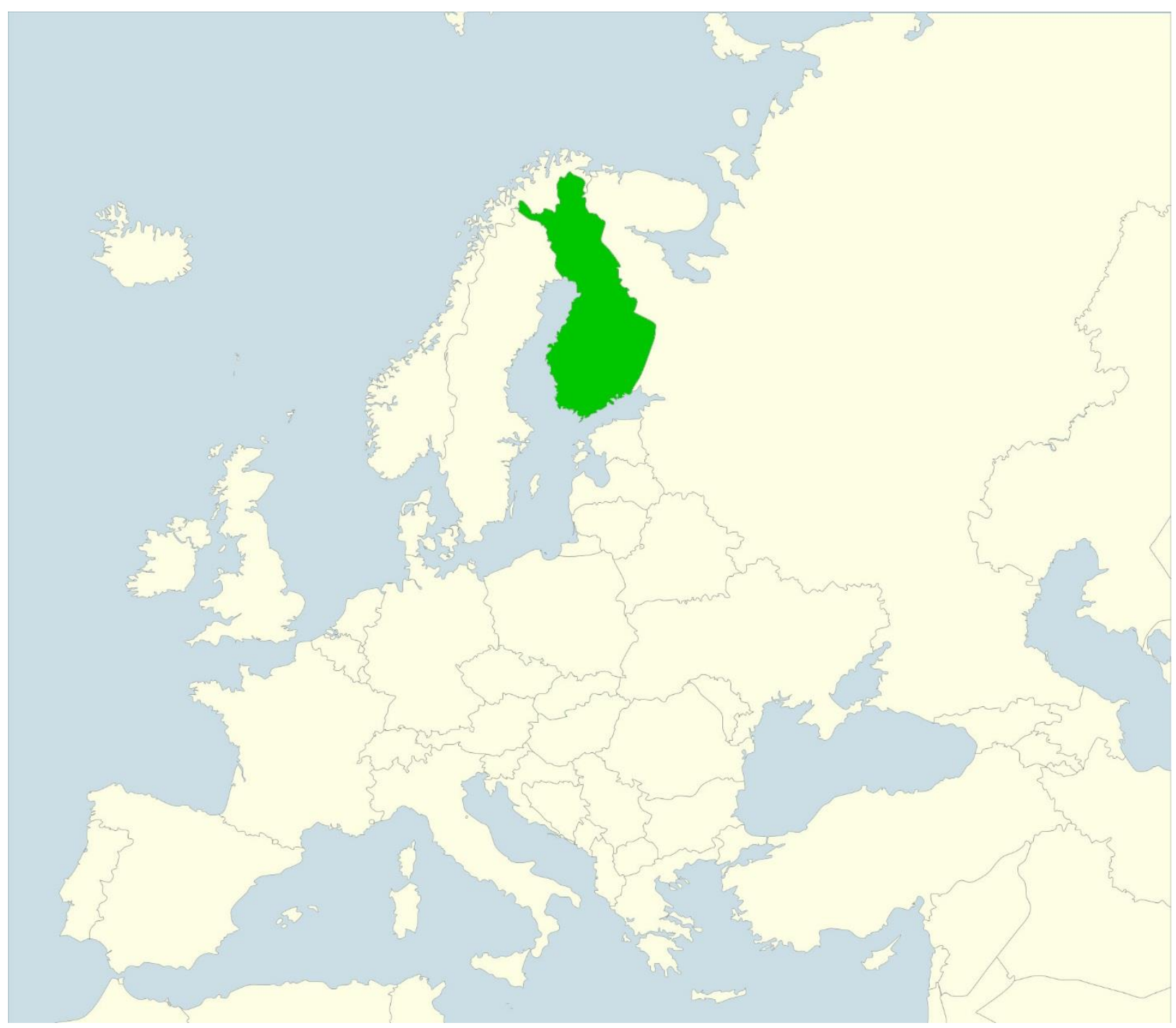

\footnotetext{
${ }^{1}$ Emilia Rönkkö, Dr. tech., University of Oulu, School of Architecture, Pentti Kaiteran katu 1, 90014 Oulu, Finland; e-mail: emilia.ronkko@oulu.fi

${ }^{2}$ Eeva Aarrevaara, Principal lecturer, Dr. tech., Lahti University of Applied Sciences, Ståhlberginkatu 10, 15110 Lahti, Finland; e-mail: eeva.aarrevaara@lamk.fi
} 
Abstract: In this article, we will introduce the topic of strengths-based planning strategies for rural localities in Finland. The strengths-based approach focuses on capacity building and competence enhancement with the local people, encouraging communities to valorise, identify and mobilise existing but often unrecognised assets. Setting focus only on the deficiencies and problems easily inflicts a 'surrender mentality' in places outside of the urbanisation impact, creating a narrative that both decision-makers and community members start to believe. Hence, the role and potential of smaller rural localities is easily forgotten by planners, politicians and the public at large. Addressing the scale of rural localities in spatial planning, we will first reflect upon the main findings from our earlier research project "Finnish rural localities in the 2010's" conducted by Lahti University of Applied Sciences, the University of Oulu and Aalto University in 2013-2015. Findings from the research project affirmed the unfortunate consequences of rapid urbanisation, rational blueprint planning and overoptimistic expectations of growth in the 1960s and 70s, which have resulted in the state of permanent incompleteness in rural localities today. However, these localities possess many under-utilised strengths, and we consider it essential for the future development of rural localities to make the most of this potential, and not only tackle the downwards spiral. This requires the ability to engage local stakeholders around a common vision for the future, and strategic approach based on endogenous strengths. We will discuss these possibilities via two theoretically informed case studies. The first one, Vieremä, is situated in the region of Northern Savo, and the other one, Vääksy, is the main centre in the municipality of Asikkala, situated in the region of Päijät-Häme in Southern Finland. Our study design can be characterised as qualitative research benefiting from a case study approach, mixed methods research and participatory action research. Being critical-emancipatory by nature, the exploratory and normative perspectives of Future Studies have also provided methodologies to explore future alternative paths and the available, yet possibly hidden, resources of people, commodities and skills in new ways. Through these case studies, we have identified an urgent need for capacity building and preparedness for sustainable resource management in Finnish rural localities, including natural and cultural heritage protection, climate change management and human well-being. There is a need to start thinking creatively 'outside-the-box' and create strategic alliances between civil society, business and government, and most importantly, between urban and rural areas. Now is the time to start innovating a range of policy options and strategic objectives for addressing rural localities as places where a sustainable future can be developed in Finland.

Keywords: rural localities, strengths-based planning strategies, context-sensitive planning, resource wisdom, cultural sustainability

\section{Introduction}

A recent OECD territorial review (2017) encourages northern sparsely populated areas (NSPA) in Finland, Norway and Sweden to identify their strengths and absolute advantages, and come up with strategies to secure future growth and prosperity. Despite the fact that NSPA regions share joint challenges including harsh climate, fragile natural environments, sparse population and long distances from markets, these areas are gaining increasing global attention due to geopolitical and economic interests. Undeniably, many major challenges, such as the transition to a bio-economy, sustainable provision of food, or the scarcity of freshwater, have essentially rural solutions (Kuhmonen \& Kuhmonen, 2015). On the other hand, large-scale investments related to e.g. mining, biomass utilisation or growing international nature-based tourism involve a potential risk of exploitation and loss of local natural and heritage values, which endangers the environmental and cultural sustainability of these regions. Despite growing interest towards the resource potential of northern peripheral areas, in times when public discussion is mostly evolving around urbanisation, the role and potential of smaller rural localities is easily forgotten 
by planners, politicians and the public at large. They are also neglected in terms of policy frameworks, causing them to fall between urban development strategies and policies for disadvantaged peripheral villages. Even within academia, intellectual monocultures tend to dismiss the diversity of the rural areas (Kuhmonen \& Kuhmonen, 2015), and facts about unemployment, lower incomes, social exclusion, the decline of local services and a general feeling of losing power are often overly generalised as 'rural deprivation' (Moseley, 2003, 1-2). On this account, we are addressing especially the spatial scale of rural localities, a fundamental concept of settlement structure, which is spatially distinguished from sparsely populated areas. (Helminen et al., 2016). Localities are generally defined as areas with at least 200 inhabitants while the distance between buildings is less than 200 metres. The Finnish Environmental Institute (SYKE) has recently published a more accurate typology of localities in eight different categories where urban and rural localities are separated. Rural localities are further divided into four categories based on their population and area density: large rural locality, rural fringe settlement, middle-sized rural locality and small rural locality. The biggest localities are densely built areas with over 3,000 inhabitants, usually surrounded by more sparsely populated fringe settlements. Middle-sized rural localities have at least 1,000 inhabitants and are densely built, while small rural localities have less than 1,000 inhabitants. It is concluded that these descriptions ought to be further delineated by dividing localities into different community types, based on their role in regional and community structure, economy and other societal functions (Helminen et al., 2016).

As a background for this paper, we will first discuss in brief the historical development and present state of Finnish rural localities, reflecting on our previous research project "Finnish rural localities in the 2010 's" conducted by Lahti University of Applied Sciences, the University of Oulu and Aalto University in 2013-2015 (Aarrevaara, 2015). The qualitative study design included seven in-depth analyses of rural towns and communities located in different parts of Finland. Their development trajectories during the past thirty years were reviewed based on cartographic analyses and archive studies, empirical field analyses and participatory workshops in the case municipalities. Our notions on the root causes of the current challenges can be divided into three main categories: firstly, deficiencies in existing policies and regulatory systems, causing them to match poorly with the specific needs of rural localities in spatial planning; secondly, weakened status of the local centre as an activity 'hub' and a deteriorating built environment; and thirdly, lack of recognition of the cultural environmental assets and distinctiveness of the place.

The statutory planning system, which came into effect in the Finnish countryside in the late 1950s, was characterised by the ideals of rational blueprint planning and urban growth. In the 1960s and 1970s, planning processes resulted in oversized building rights and presumptive property values in rural municipality centres. This provoked landowners into land speculation, resulting in the demolition of old heritage buildings. The existing built environment was replaced with monotonous concrete infrastructure and a uniformity of appearance that was similar all over the country. As this happened simultaneously with the proliferation of private car use, 'airstriplike" lanes and large paved surfaces are symptomatic to the townscape of Finnish rural localities today. In conclusion, the rapid transformation from organically grown rural parish towns to planned modern service centres resulted in a typology of 'clone towns' (Knox \& Meyer, 2009) lacking a distinctive sense of place and recognisable visual character.

This problem has much to do with the struggle to maintain the commercial viability of the local centre, as the development of centralised supply chains and concentration to bigger edge-of-town supermarket units have continued. The status of local centres as hubs for activity has been especially compromised when municipalities have administratively merged, or in cases where the centre has effectively 'wandered' away from its original location due to economic displacement or the vicinity of the rural locality to bigger urban centres. Furthermore, the standard practice, especially since the 1980s and 1990s, of investing in road bypasses has had a negative effect on the former commercial nodes.

Our findings also affirmed the unfortunate consequences of rational economics and overoptimistic expectations of growth to cultural heritage protection. Negative attitudes towards heritage preservation have been rather persistent in many rural municipalities, even though critical voices gained ground already in the late 1970s as people realised the outcomes of drastic and rapid environmental changes. Despite the greatly overshot growth predictions and gap between 
the abstract plans and results, the ideal of community planning in favour of transforming rural localities into viable 'miniature cities' still seems to hold on. To sum up, rural localities are left in a state of permanent incompleteness.

Despite several challenges and a rather unfortunate historical development, we think that there are also several strengths and reasons why rural localities should be regarded important in fostering sustainable development in Finland. First, transitioning to a green economy necessitates a robust settlement system that gives access to a decentralised use of natural resources. Secondly, nature and cultural heritage still visible in rural localities play an important role in the local and regional identity, and the local ecosystems can provide an advantageous context for adaptive community development connected with social and cultural concerns. Thirdly, and most importantly, rural localities offer a high quality of life and well-being to inhabitants with a combination of attractiveness, affordable prices, safety and a slower pace of life as opposed to hectic work-and-spend lifestyle in cities. In this regard, we agree with Knox \& Meyer (2009) that small rural localities can be developed towards sustainable niches in the regional, national and global economies by wisely leveraging their environmental and socio-cultural assets and building on comparative advantages (Knox \& Meyer, 2009, 11). In the following chapters we will provide an overview of the theoretical and methodological premises for developing spatial planning processes towards culturally sustainable and strengths-based orientation. Thereafter we present our findings from two recent case studies, one located within the resource-based economy of northern and eastern Finland, the Northern Savo region, and another located within the servicebased economy of southern and western Finland, the Päijät-Häme region.

\section{Theoretical background: contextually sensitive and strengths-based community planning}

As highlighted in the previously mentioned OECD report, sparsely populated northern regions are encouraged to identify their strengths and advantages. Theories and discussions on the nature of competitive advantage and the 'resource-based view' emerged within economics since the mid1980s (Roney, 2010). Later on, several issues regarding e.g. the narrow economic rationality and the static nature of resources as it was originally conceived in resource-based theory, have been brought up. There has also been suggestions for moving into a more dynamic framework where resources could be understood as the basis for sustained competitive advantage, i.e. the capability to adapt by reinventing resources and finding new linkages between them (Roney, 2010; Kraijenbrink, Spender \& Green 2010). Whereas the resource-based line of thought stems from economics, the strengths-based view has its origins in community psychology (see e.g. McCammon, 2012), focusing on capacity building and competence enhancement with the local people. The strengths-based approach can be seen as synonymous with the so-called Assetbased Community Development (ABCD) approach, which emerged in North America in the 1990s as an alternative to 'needs-based' approaches to development. Since then, ABCD has been considered to be an innovative strategy for community-driven development both in urban neighbourhoods and rural communities (Mathie \& Cunningham, 2003). Contrary to the rather negation-oriented need-based view, Asset-based Community Development encourages communities to build an inventory of their assets and see value in resources that would otherwise have been ignored, unrealised or dismissed. As Mathie \& Cunningham (2003) put it, "ABCD rests on the principle that a recognition of strengths and assets is more likely to inspire positive action for change in a community than is an exclusive focus on needs and problems." It can be understood as an approach, as a set of methods for community mobilisation, and as a strategy for sustainable community-driven development (Mathie \& Cunningham, 2003). It should be noted that in its original meaning in community psychology, "community" is not necessarily restricted to territorial boundaries or geographical location - it has to do more with the social interactions of people. Within spatial planning, the term 'community' is understood contextually, as a territorial community where most residents have the feeling of belonging to the same place and sharing a common identity (Moseley, 2003, 75). Introducing the strengths-based view to the sphere of physical community planning similarly contains the basic premise that people in communities can drive the development process themselves by identifying and mobilising existing but often 
unrecognised assets. These aspects are also considered essential in place-based development which involves the local population in community-led development (Hambleton, 2014).

In many respects, the strengths-based approach is also related to the principals of Participatory Appreciative Action Research (PAAR) and appreciative inquiry (AI), which are based on the idea that people should be involved and empowered in the management of the social-ecological systems of which they are a part (Ghaye et al., 2008). Methodologically, appreciative inquiry (Al) is a process that promotes positive change in organisations or communities. It focuses on collective analysis of the elements of success and shared meanings, instead of seeing itself in largely negative terms (Elliot, 1999). In particular, the appreciative attitude affects how problems are faced and solved when emphasising a reflective learning framework, and it is about identifying and sustaining strengths-based strategies (Ghaye et al., 2008; Healey, 1997). Focusing only on the deficiencies and severity of problems easily inflicts a 'surrender mentality' in rural localities, a narrative that both decision-makers and community members start to believe. The strengthsbased approach has the objective of not getting 'locked' into the current state of affairs. Accordingly, the strengths-based approach emphasises the importance of preparedness and adaptive capacity building, i.e. the ability to respond to foreseeable and unforeseen changes.

In order to support the inclusion of social and cultural values in strengths-based planning, we are also referring to the concept of cultural sustainability (Soini \& Birkeland, 2014) as we reflect upon the viability of rural localities and their ability to find adaptive strategies for future existence. Cultural sustainability, as the integration of culture in sustainable development, was first mentioned in the World Commission on Culture and Development definition (WCCD, 1995). Since 2001, there have been several efforts to add culture as the fourth sustainability pillar initiated by the UNESCO Universal Declaration on Cultural Diversity (UNESCO, 2001; Hawkes, 2001). However, the understanding of culture within the framework of sustainable development has remained vague, and culture has not been systematically included in sustainable development policies, practices or assessments (Soini \& Birkeland, 2014; Soini \& Dessein, 2016). According to Soini \& Birkeland (2014), the scientific discourse on cultural sustainability and the use of the concept have evolved around several storylines such as heritage, vitality, economic viability, diversity, locality, eco-cultural resilience and eco-cultural civilisation. The latter, eco-cultural civilisation storyline especially embraces culture as a necessary foundation for the transition to a truly sustainable society. In this respect, cultural sustainability in community planning is about passing forward cultural values spatially embedded in particular places to future generations. This kind of contextual approach is always appreciative towards local circumstances and seeks responses that promote sustainability from a holistic perspective. As stated by LaGro, contextsensitive development has three fundamental precepts: design with nature, with culture, and for people. This means integrating natural structures in man-made structures, adjusting the old with the new without discrepancy and maintaining a continuing link with the past and with a place's identity (LaGro, 2008, 192, 210-211). Such an approach incorporates rather than destroys significant natural and cultural amenities in land use plans and forms a holistic basis for sustainability. A holistic and systematic approach to sustainability also necessitates that programmes and policies combine the goals of economic, socio-cultural and environmental sustainability (Campbell, 1996).

\section{Methodology to support strengths-based community development}

This section of the paper illustrates the concept of strengths-based community development through two different spatial planning projects conducted in the rural localities of Vieremä and Vääksy (Figure 1.) These planning experiments were coordinated by the authors in the University of Oulu (Vieremä) and the University of Applied Sciences in Lahti (Vääksy), together with Masterlevel students in urban planning. 


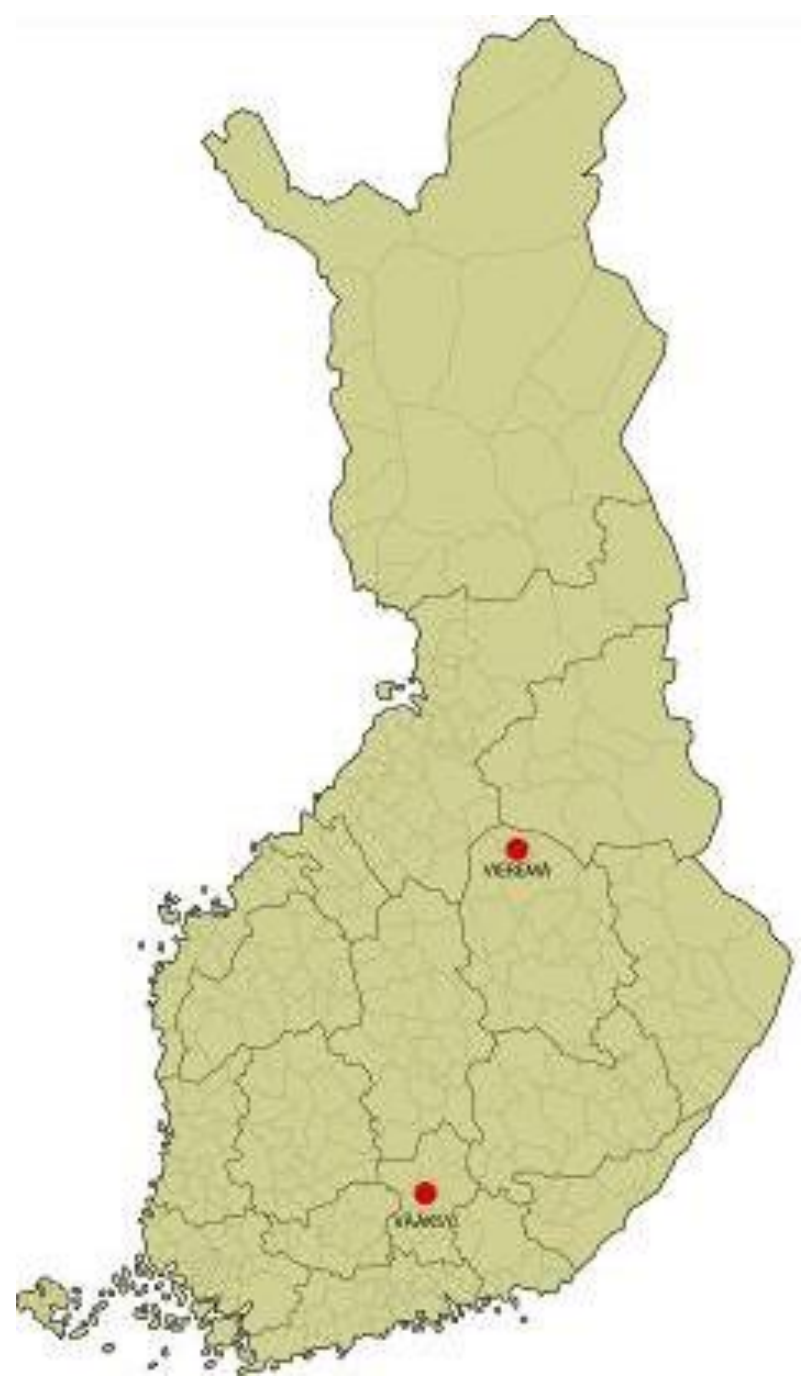

Fig 1. Location of the case study municipalities.

While our previous research project on Finnish rural localities depicted their transformation processes and current state, these subsequent two case studies were oriented towards illustrating the processes of creating alternative development paths towards a culturally, ecologically and economically sustainable future. These 'Rural Design Studios' served as laboratories for examining the types of participation, co-creation and planning processes that are needed given the future lifestyles and the effects of digitalisation, new kinds of service concepts, transportation, local food, bio-economy and generally living in harmony with the natural and cultural resources. Our study design can be characterised as qualitative research in community development, benefiting from a case study approach, mixed methods research and participatory action research. Being critical-emancipatory by nature, the exploratory and normative perspectives of future research have also provided methodologies to analyse and arrange multiple change factors and weak signals in the environment to alternative future paths (Quay, 2012; Oliver, 2014; Wilenius, 2015). In Vieremä, a scenario planning method was applied as a design tool in social learning (Kuhmonen \& Kuhmonen, 2015). It has a long history in tackling complex and wicked problems (Rittel \& Webber, 1973) and uncertainty of the future. It was introduced into Finnish spatial planning processes in the early 1980s (Sneck, 1983). The scenario method has generally two main components: exploratory and normative (Oliver, 2014, 46). The former strives for examining and probing possible future development paths. The latter is focused on assessing potential eligible, risky or otherwise possible future states, and the means upon which these can be avoided or achieved. What is relevant for the strengths-based approach is that the scenario method also allows exploring the available, yet possibly hidden, resources of 
people, commodities and skills in new ways, and identifying collectively acknowledged opportunities or unforeseen linkages between different assets.

\subsection{Vieremä - A development strategy for a resource-wise future}

As part of the Strategic Planning education in the Oulu School of Architecture, we carry out each year a spatial planning project in cooperation with a Finnish rural municipality. Apart from the pedagogical importance, these projects have also become significant methodological research tools focusing on rural planning issues. As the project is commissioned by a real client, we work on solutions to actual development challenges specific to the place. In 2016, we worked together with Vieremä, a rural municipality with ca. 3,700 inhabitants located in the Northern Savo region.

The four-step process included three field trips during the autumn of 2016, and altogether five workshop sessions with the local steering group. This core group of community members participated in collaborative visioning throughout the process. The members of the group were identified and recruited with the help of local authorities. The main criterion for the member selection was that the group should be as heterogeneous as possible, representing different interest groups within the community in order to alleviate possible perspective bias. In the first phase, we focused on mapping and analysing the community assets and discussing the existing strengths. This discussion was preceded by a study on the historical transformation processes, which was a combination of statistical, archival and cartographic analysis. It formed a basis for understanding the cultural and heritage resources, local significance of places and other characteristics in the case locality. Qualitative data was supplemented with statistical data of the community structure, buildings and infrastructure, service network, population and work places (Figure 2). Furthermore, a residential questionnaire was conducted in order to map the views and opinions of the locals. This was performed with a public participation GIS-tool (eharava.fi) that gathered place-based comments and insights from the locals (Figure 3). The questionnaire, also available in paper form, included both structured and open questions, which were analysed in four thematic categories concerning the functional, physical, sensory and socio-cultural environment. The total amount of responses was 130, of which 88 were eventually accepted for analysis.

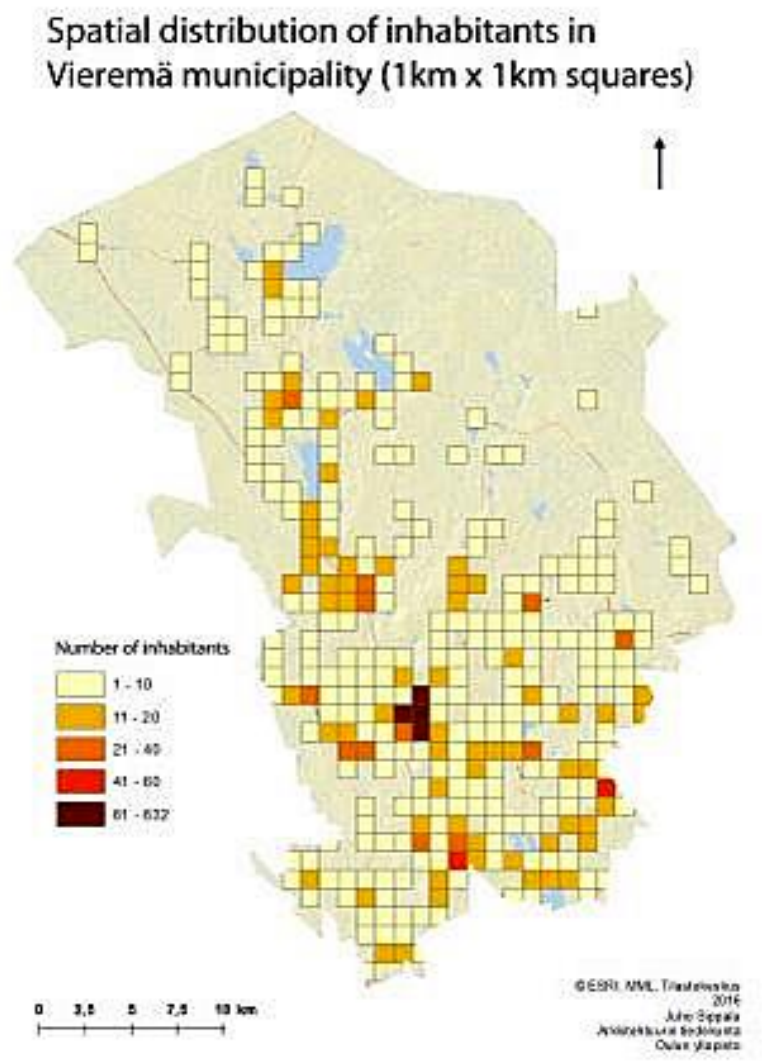

Fig 2. Spatial distribution of inhabitants in Vieremä municipality (@ University of Oulu / Juho Sippala). 


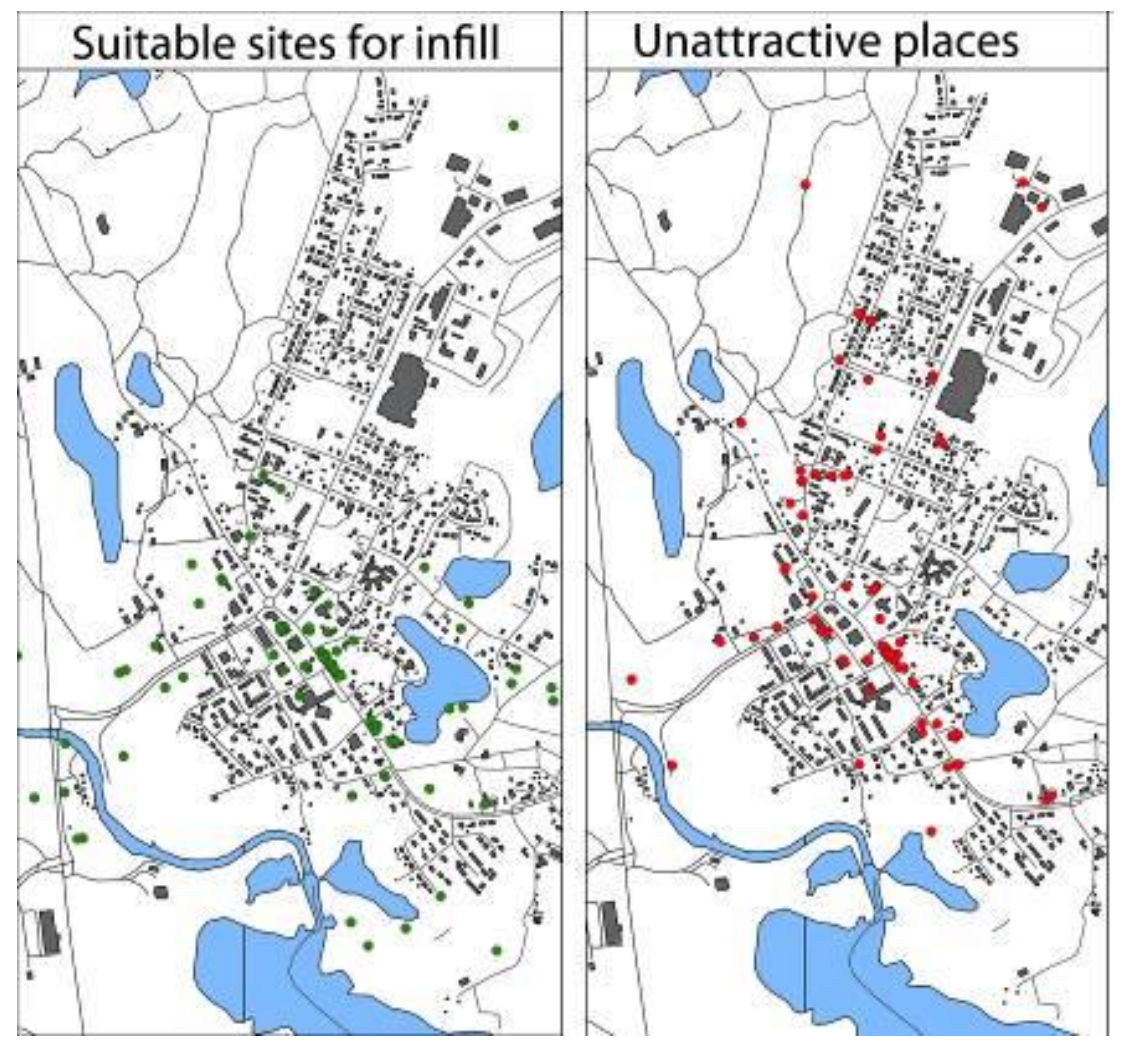

Fig 3. The map-based questionnaire revealed public opinions regarding e.g. suitable sites for infill and unattractive places. These sites mostly overlap. (@ University of Oulu / Sauli Partanen)

Empirical site analysis was categorised accordingly into four areas of investigation across a range of information inputs: functional, structural, sensed and experienced characteristics (Figure 4). In order to avoid a 'fishing expedition' or an open-ended investigation (LaGro, 2008, 102), we utilised a methodological framework called TRIM (Rönkkö, 2012; see also Rönkkö, 2017).

The functional environment, consisting of land use, livelihoods, connectivity, services and amenities, can be regarded as the 'heartbeat' of the locality. In Vieremä, people's livelihoods are strongly based on two industries: agriculture and the metal and technology industry. In principle, one could see a need for economic diversification and reducing people's dependence on a single industry or two. Yet, there are already signals of ecosystem facilitation around the lead company Ponsse, and innovations sprouting around it in a group of smaller companies. Generally, userdriven innovations take place when the entrepreneur cannot find a viable solution from the market and is compelled to develop a way to resolve the problem. As noted also by the OECD report (OECD, 2017), local user-driven innovations do not usually go far from the origination point, but in some rare cases, as it has happened in Vieremä, local innovations can alter global markets. The timber harvester developed by Ponsse is now the main technology for commercial tree harvesting around the world. This significantly adds to the economic vigour of the entire region.

The structural environment, which can be regarded as the 'backbone' of the settlement, is formed by the built physical infrastructures and utilities, and outlined by the topography. Vieremä is a fairly compact ridge-hill settlement, even though residential development has to some extent spread to the surrounding fields. The number of old heritage buildings is quite low, and the fragments that still exist do not form thematic entities within the built fabric.

Our analysis of sense-scape focused in turn on perceived qualities and produced information about the scenic quality, or 'face', of the locality. As in most Finnish rural localities, the micro landscape within the settlement is fairly incoherent and needs to be improved. However, the macro landscape, together with surrounding wilderness areas offering nature-based experiences and well-being, are significant, though under-utilised local assets. Better recognition of these resources would be necessary, as for example, new areas for housing development in 
open agricultural areas, large-scale utilisation of soil from the sandy ridges, or wind farming might have negative impacts on the attraction resources.

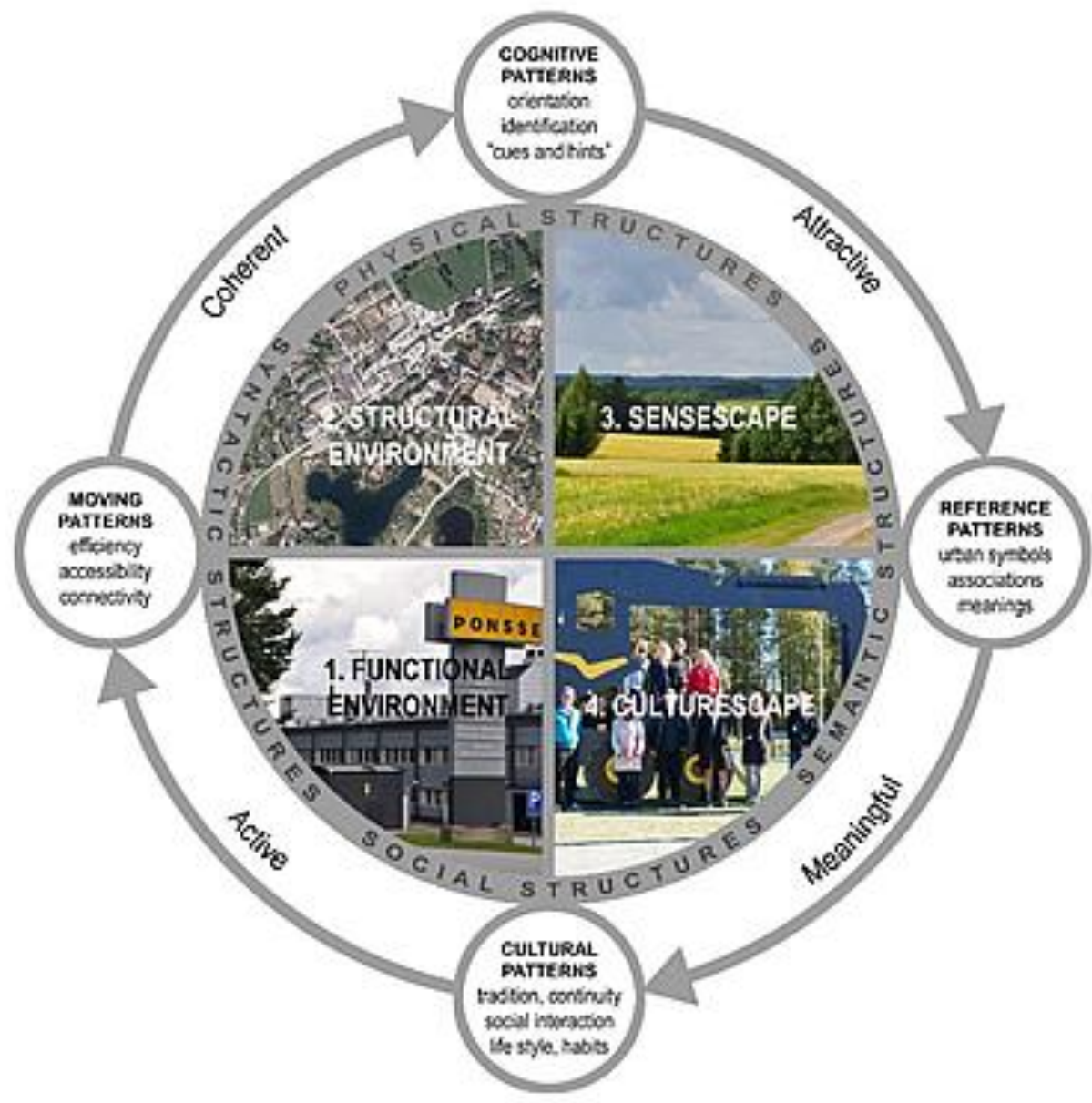

Fig 4. TRIM - framework: Four thematic areas of investigation: functional, structural, sensed and experienced place attributes.

Valorisation of local cultural values was also an important part of the contextual analysis. Local culture-scapes formed by the tangible and intangible aspects of cultural systems, symbolic meanings and traditions ultimately create the 'spirit and soul' of the locality. In Vieremä, these aspects are largely rooted in the exceptional success story of Ponsse, which has created a collectively shared feeling of pride among the community members. This was rather wellexpressed in one of the anonymous answers to our questionnaire, stating that "people are walking around wearing promotional clothing by Ponsse, both in weekdays and during important occasions." Accordingly, their active participation in events organised by the local association, Kylänraitti ry., has created a collaborative culture of doing things and a strong sense of togetherness. Based on our appreciative inquiry, communality and the sense of togetherness could be regarded as one of the most important assets in Vieremä.

Our analysis identified several strengths embedded in the physical, social and cultural environment of Vieremä. Based on dialogue with the local steering group and our own analysis, we preselected a range of drivers possibly affecting the future state of Vieremä. This phase was also informed by the latest national and regional statistics and trends. Taking all of the information gained as a starting point, and discussing with the local group, we constructed strategic scenarios to explore future development paths and their possible consequences within three alternative thematic scopes: 1) locality-bound lifestyle trends and nature-based well-being; 2) growing demand for green energy and decentralised use of natural resources; 3 ) facilitation for specialised technological development and competence. We had three planning groups which were each given a presumption for population change for the target year 2040: status quo, moderate growth or substantial increase. The idea was to make the scenarios distinctively different, revealing 
multiple perspectives around the identified strengths. In each case, the group had to innovate and envision novel solutions which promote functions that use the local resource base in sustainable ways; utilise new or existing infrastructure supporting robustness; add value around contextspecific, immobile and/or immaterial resource assets, such as landscape; and foster positive aspects contributing to communality, social activity and civic engagement.

The scenarios were named accordingly by their thematic emphasis. The first strategic scenario, titled 'Well Be Vieremä', was based on the assumption that the amount of permanent residents would not grow, and strategic focus would be put on high quality of life, nature-based tourism and culture-led community development. The second scenario, titled 'The Power of Vieremä', was based on moderate population growth and strong focus on agriculture and sustainable energy production. The third scenario, 'Vow Vieremä!' was founded on the emergence of new lines of industry around high technology in robotics and automation, which would also support the existing economic pillars. With significant population growth expectations, this development trajectory would double the population size by 2040 .

On the third phase, strategic scenarios and their expected impacts were evaluated together with the local stakeholder group. In the fourth and last phase, we compiled a final strategic plan titled 'Luminous Vieremä 2040' for a resource-wise future as a synthesis of all the preceding phases, prioritising and optimising a combination of responses to achieve the desired goals. The outcomes of the planning process were also successfully linked with the new municipality strategy. A specific development target was to revive the centre as an activity node. The municipality intends to realise the first stage improvements regarding the new public square in summer 2017. (Figure 5).

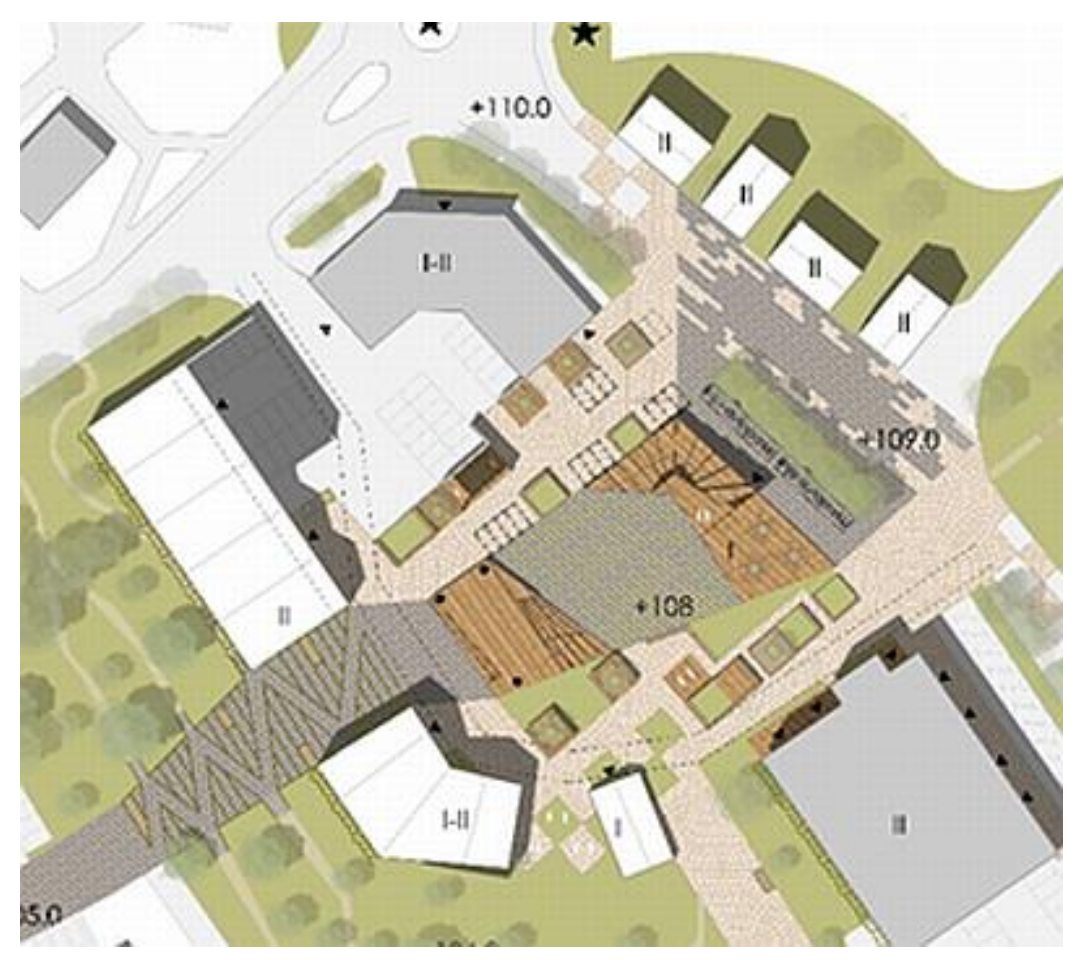

Fig 5. Plan for the new public square (@) University of Oulu / Eskelinen, M.; Hukkanen, JP.; Juujärvi, M.; Lehto, I.; Murtola, S.; Määttä, R.; Partanen, S.; Peteri, EL.; Saukkonen, M. \& Syrjäpalo, AJ.).

\subsection{Vääksy: How to support cultural sustainability by citizen activity - debates between stakeholders}

This case study introduces the cultural environment of the rural locality of Vääksy and especially its canal environment, which still generates quite contradictory opinions among local citizens and authorities, despite its recognition as nationally valuable. The different viewpoints recently culminated in the building of a modern apartment building in the valuable environment. Nevertheless, in recent years, a new kind of citizen activity has been expressed through an association dedicated to the development of old Vääksy. The association aims to enhance 
the preservation of the cultural environment and old buildings in Vääksy and participates e.g. in detailing planning processes concerning the traditional environment. Several events have been arranged by the association, such as "Open houses and yards" each autumn, in which private householders allow regular people to visit their traditional houses and property for a weekend. The local association also wants to contribute to the discussion about complementary building in the canal environment and present alternatives to apartment buildings (Vanha Vääksy, 2017). In 2016 the association became a partner in the "Well-being and business from cultural environment" project. The idea for the project came together in discussions between the association members together with the University of Helsinki and Lahti University of Applied Sciences in 2014-15 amidst growing concerns among the citizenry regarding complementary building in old Vääksy. The association became increasingly worried about the state of the traditional environment due to the pressure to build more new apartment houses near the canal (Järvien ja harjun solmukohta, 2017).

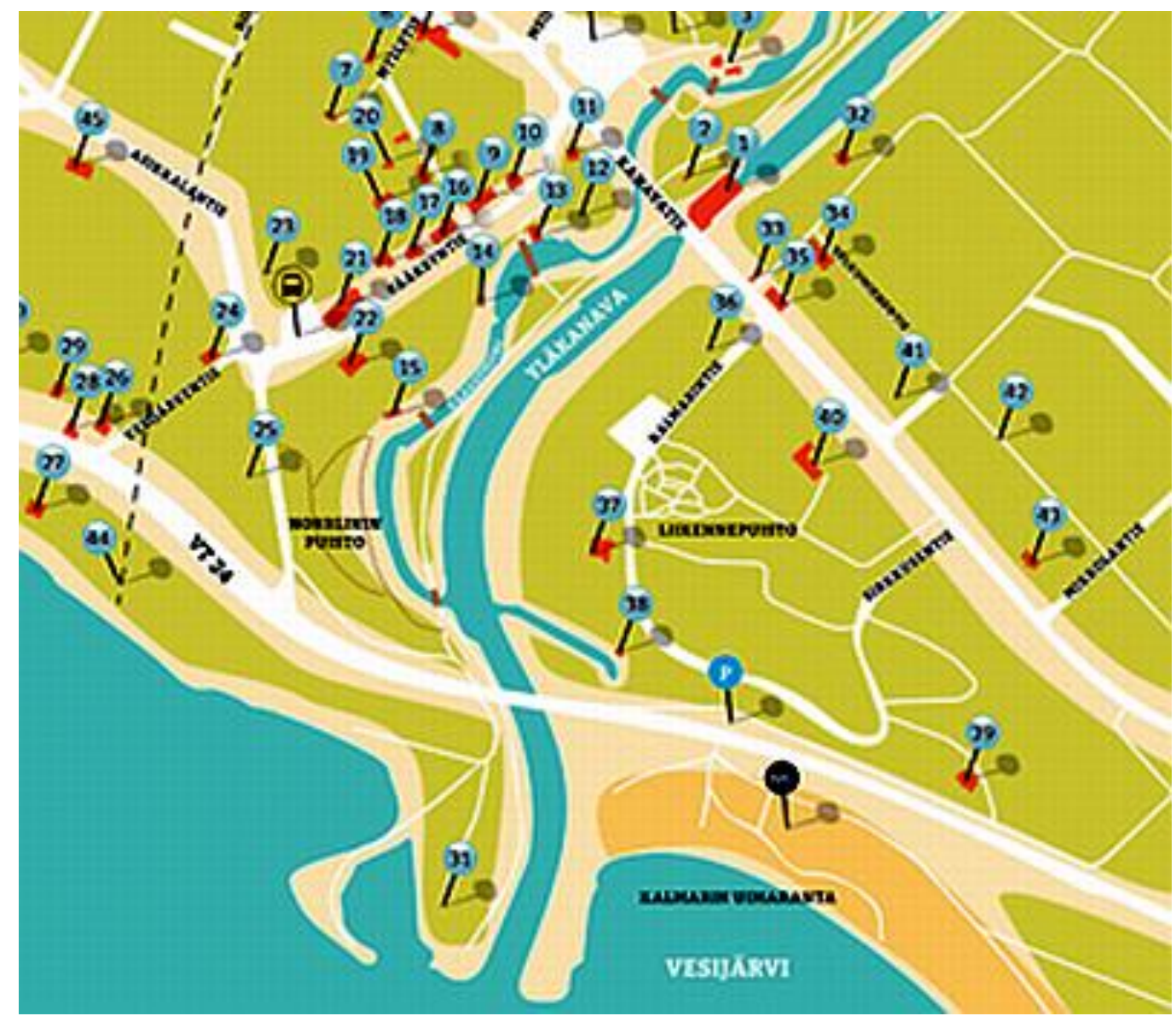

Fig 6. The Vanha Vääksy association has provided a walking tour map in their homepage. When the user clicks the number of the target, a new page will be open, telling more about the history of the chosen place and its buildings (Vanha Vääksy, 2017).

The project is coordinated by the University of Helsinki Centre for Continuing Education while Lahti University of Applied Sciences (LAMK) also works as a partner in it. The project is funded by the local LEADER action group. The University of Helsinki is responsible for collecting stories connected with the cultural environment, its history and inhabitants, whereas LAMK is responsible for updating the 20-year-old cultural environment programme in the Vääksy area.

\section{Landscape and the built environment of the rural locality}

A map of the rural locality of Vääksy (Figure 7) presents the unique situation in the local landscape: The ridge formation of II Salpausselkä crosses with the Vääksynjoki River and the canal of Vääksy, which was built in the late $19^{\text {th }}$ century. The canal and the traditional settlement in its environment are classified as a nationally valuable environment. Vääksy is 
the main centre of the municipality of Asikkala, which has 8,287 inhabitants (31 December 2015), and is included in the jurisdiction of the Regional Council of Päijät-Häme, which is responsible for the regional planning of the whole area (Asikkala, 2017).

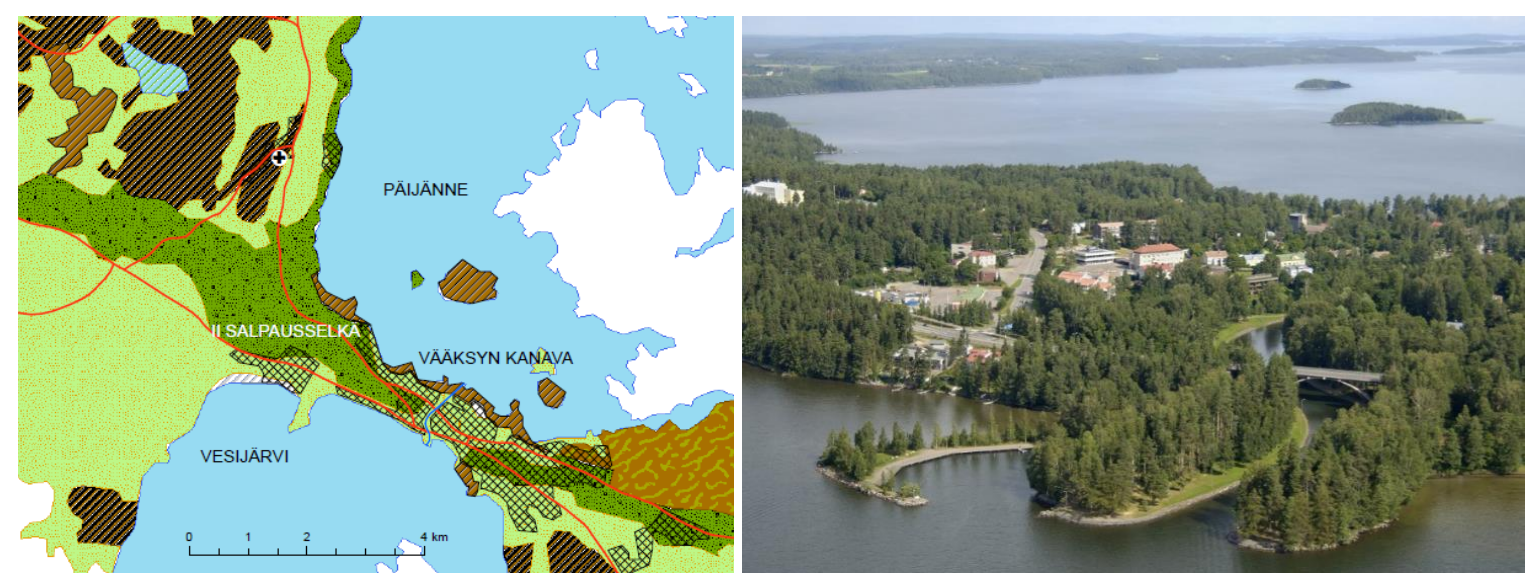

Fig 7, 8. The map and aerial picture present the situation of the rural locality on the crossing of the ridge formation of II Salpausselkä and the watercourses of Lake Vesijärvi in the south and Lake Päijänne in the north (Copyright Lahti University of Applied Sciences).

The canal of Vääksy and its constructions represent the high epoch of canal building in the late $19^{\text {th }}$ century (Figure 8). The 1,300-meter long canal connects Lake Vesijärvi and Lake Päijänne with a lock. Typical canal buildings have been preserved in the milieu and an old villa area is in the neighbourhood. The Vääksynjoki River is situated on the west side of the canal and is one of the oldest mill placements known in the municipality, mentioned in documents already in the $15^{\text {th }}$ century. A medieval road line also crosses the Vääksynjoki River. The need to build the canal became obvious in the 1860s when the decision concerning a railway connecting Riihimäki with St Petersburg was made. The canal enabled shipping between Lake Päijänne and the harbour of Lahti. The canal was opened in 1871. Since then, it has become the busiest canal in Finland by traffic volume. The settlement started to grow in the surrounding area, and because of the canal, the rural locality of Vääksy became the centre of the municipality (Valtakunnallisesti arvokas rakennettu kulttuuriympäristö, 2017).

\section{Complexity of protection and preservation}

Cultural environments should be acknowledged in planning processes both at the regional and municipal levels, according to the Land Use and Building Act (1999). The main principles of clear and updated inventories are required by regional authorities when municipalities are initiating new planning projects at the master or detail levels. Still, controversial interests dealing with cultural environments and valuable buildings are regularly found. The results of legal appeals are hard to predict in each case.

In the 1990s, the Ministry of the Environment launched a model for a cultural environment programme and encouraged several municipalities to start the work. Programmes were prepared at the municipal and regional levels. Asikkala got its own cultural environment programme in 1998. The aim of the programme was to collect information from different sources as well as introduce the area and its typical cultural heritage, combining landscape and built environment as well as archaeological sites and general history. A detailed description of valuable areas and sites was included in the programme, based on previous inventories at the national, regional and local levels. Usually, at the local level, there has been a need to complete inventories of the built environment. For example, the importance of different elements, such as small warehouses, fences and vegetation, as essential parts of built sites and roads, was illuminated. After all, the cultural environment programme is a report that collects information of the local environment and provides advice to the municipality and the local landowners on how to take care of the buildings and the environment. 
In the Asikkala cultural environment programme (1998), the canal and the surrounding park and built environment, the old Vääksy settlement, the Kanavatie road with its milieu and the old buildings of the Anianpelto village - an old market place with its pine forest, were mentioned as the most important areas needing sensitive care in the future. Old villas and the manor house were also included in this list. Fragments of the old settlement structure have been preserved in the eastern side of the canal, such as old wooden villas and commercial houses. In the western side of the canal there is more coherence in the traditional settlement, the original old Vääksy, which consists of residential buildings, a pharmacy, a hotel and commercial buildings (Wager, 2006, 25-26). The scale of the buildings (Figure 9) has remained similar, and the environment is an attractive one, with several places such as shops, accommodation services and cafes. The canal itself is the biggest attraction in the environment (Figure 10).

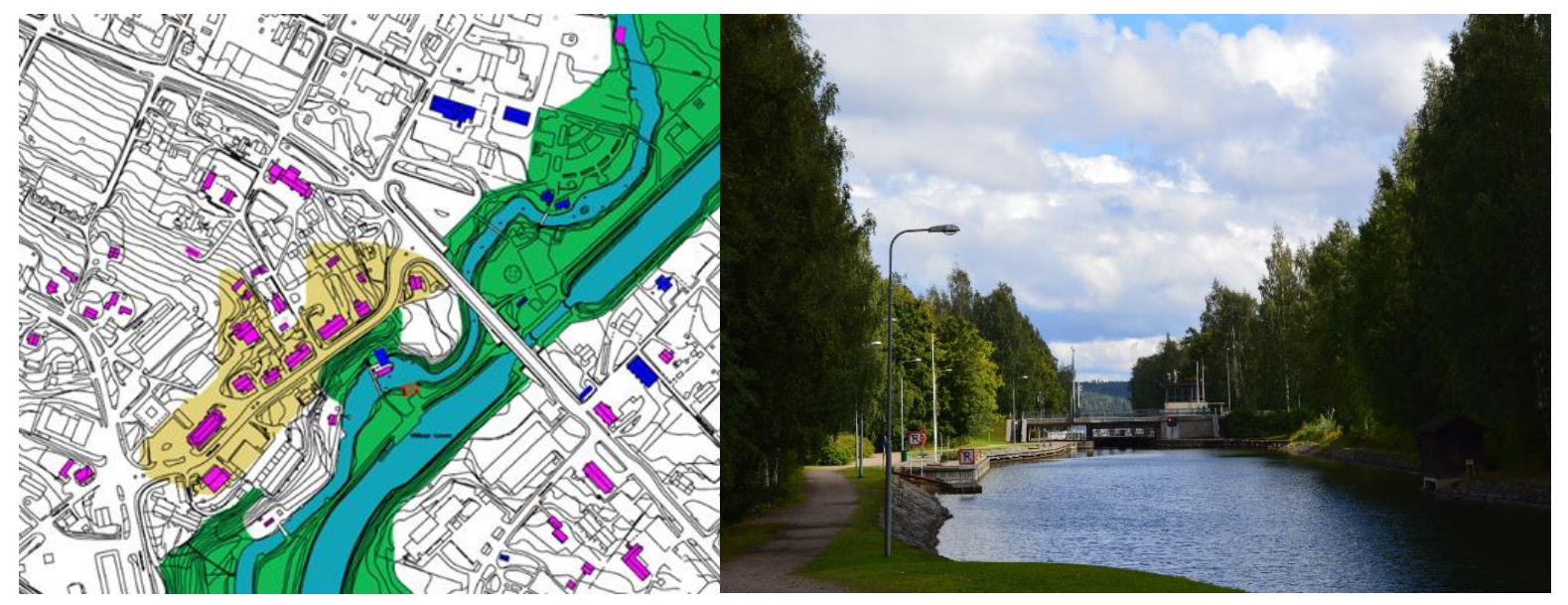

Fig 9, 10. The map presents the milieu of the old Vääksy (marked as light brown), the canal and the Vääksynvirta River with the park area. The buildings coloured in purple are included in the cultural environment inventory, mostly dating back to the early $20^{\text {th }}$ century. The view opens to the lock of the canal (Map and photo: Marjut Kakko).

It can be argued that the old built environment has been partially preserved because the main commercial centre of the town is situated on the other side of the canal. The modern market area and apartment houses form a new kind of rural centre - one that is more anonymous and representing planning ideas which started to change the environment from the 1970s and 1980s onwards. Currently, the environment is dominated by car traffic and built to a different scale compared with the old parts of the town. The buildings along the main road combining the old and new parts of the town are actually quite heterogeneous. In discussions, it has been identified that the road environment needs conscious development measures in order to merge these different parts together.

In 2010, the construction of a modern apartment building in the historical canal environment incited strong opinions among the local citizens, authorities and municipal politicians. The municipality decided to give an exceptional permit to the building. Then about 2,500 citizens signed a petition against the plan and an appeal was filed to the administrative court. In addition, the regional museum filed their own legal appeal. The museum based their argumentation on the national and historical values of the canal environment. Nonetheless, the court refused to consider the appeals and the project was realised. The court justified its decision by stating that the two-storey building would not change the cultural environment of the canal (Vääksyn vesimyllymuseon naapuriin kerrostalo. Yle online news, 20 July 2010).

Although the municipality has provided updated master and detail plans in the central areas of the locality and the original cultural environmental programme (Tulonen, 1998), and compiled information about the landscape, cultural environment and their values as well as instructions for preservation in a thorough manner, it was obvious that there was an absence of a shared understanding about the cultural values and their protection principles. Interestingly, the first cultural environment programme was carried out as a consulting work commissioned and accepted by the municipal council. The updating of the programme started in 2016, but in this case the initiative came from the citizen association. It seems that citizens were more in favour of 
heritage preservation than the politicians. This conclusion could also be drawn from the questionnaire carried out by the municipality as part of the master planning process.

It is obvious that contradictory views regarding the possibilities to build in the valuable canal environment still exist. Several politicians and landowners see construction work in the attractive environment as an opportunity to gain economic benefits by selling new apartments, while other stakeholders, especially the citizens, prefer to maintain and develop the environment more sensitively based on recognition of the local heritage resources. With the growth of tourism, interest for places with a special character and identity is gradually emerging, providing other kinds of economic opportunity. Old Vääksy has already drawn positive nationwide interest. For example, in 2015, it was chosen as the winner of the small rural towns competition arranged by the Livable Town Centres Association in Finland.

\section{Results and discussion}

Vieremä and Vääksy cases have enabled us to study the possibilities of spatial planning strategy which reinforces and strengthens the local resources and character of the place. The strategic plan outlined for Vieremä showed us how to contextualise a set of place-specific solutions and alternative futures with the scenario method. In the case of Vääksy, we can identify several features related to cultural sustainability, such as heritage, vitality, economic viability and cultural resilience, which are demonstrated by the new life in the area of old Vääksy with several retail shops and services attracting local and visiting customers. Both case studies have also demonstrated the importance of meaningful participation enabling the community members to have input and control over planning, as well as having the opportunity to share knowledge and discuss and develop new ideas.

Futures Studies has become an increasingly important component for strategic planning in impact analysis, clarification of strategic alternatives, contingency planning and decision-making, to name but a few examples (Roney, 2010). In terms of valuating the usability of the scenarioplanning method in strengths-based planning, we conclude that the value of any method chosen is likely to depend as much on the success of the process, i.e. interactions and dialogue, as outputs as on the success of the outcomes, i.e. scenarios and response options. According to Waylen et al. (2015), the benefits can be summarised in three ways. Firstly, as fostering participation and community empowerment; secondly, to develop adaptive capacity; and thirdly, to support the development of systems thinking. The latter is especially beneficial in recognition or insights about the connections and links embedded in socio-ecological systems. What we would like to add and underpin is the role of designerly thinking and planning as a "practice of knowing' (Janssens, 2008; Davoudi, 2015), which most practical experiments with the scenario planning method do not recognise. Often, scenarios are presented in the form of written descriptions or narratives of the future. What we have learned from our practical experiments is that complex information and knowledge translated into a visually informative form (plans, illustrations, graphs) is particularly usable with collaborative visioning with community stakeholders. In terms of a learning methodology for architects and urban planners to be, scenario methodology within rural settings works well, as the students need to learn in practice how to make strategic choices within sustainable environmental management and human development (see Dopico \& Garcia-Vazquez, 2011).

That being said, some of the biggest challenges in the strengths-based planning approach are related to the common disinterest to participation, which has been identified in many of our other studies as well. Those who are already somehow engaged in local community governing bodies seem to be the most active. This also holds true in our case with the Finnish rural localities. Paradoxically, those who would be most affected by the local strategic plans are those who are conspicuous by their absence, namely, the youth. On that account we also recognise that our cocreation experiments are still far from ideal. Regardless of the obvious challenges, a positive notion that we have identified, especially in the Vääksy case is the change from a top-down approach on cultural heritage management towards a bottom-up approach and civic activity. Unfortunately, it seems that the activity of the citizens is not always conceived as a positive factor from the viewpoint of municipal administration. The Finnish Local Heritage Association published 
a recent report about citizen activity in protection of cultural heritage (Hirvonen \& Lohtander, 2017), which was based on 450 responses from private citizens and citizen associations. It demonstrates indisputably that citizen activity is a rising trend in this sector. However, when the goals of the municipal authorities and council members differ greatly from those of the citizens, the trust on the responsibility of the public sector decreases and active residents start to drive forward the issues that they consider important. The Vääksy case has revealed the challenges in finding a shared understanding when dealing with the development of the cultural environment and actively choosing a different strategy in development policy. There is an obvious need of making participatory practices more open-ended and supporting new ways of collectively building up the knowledge base for culturally sustainable planning. Local inhabitants, service providers, different interest groups and NGOs working in the field of culture and community-led development are important actors in sustainability management. Similarly, the role of planning authorities is very important in engaging the local community members for these kinds of activities. This is also highlighted in the National Cultural Environment Strategy 2014-2020 of Finland, which is aimed at deepening people's appreciation of their local environment and inspiring them to actively contribute to making it better by inviting people to participate in preserving and developing cultural heritage.

Regardless, the role of cultural heritage assets seems to be less visible in sustainable resource management, even though EU-level policies identify cultural heritage as a strategic resource for a sustainable Europe (Council of the European Union, 2014). Cultural environments are a nonrenewable resource that contributes to human well-being and necessitates socially and culturally sensitive policies (Auclair \& Fairclough, 2015; Council of the European Union, 2014). Policies play a key role in how different resources become valorised. Making decisions based on social and cultural values supports the growing awareness of responsible consumer choices and demand for ethical eating or lifestyles of health and sustainability, for example. We hope that in the future, lifestyles will diversify the role of rural areas as a source of nature-based welfare, even to the extent that cultural environments, similar to natural ecosystem services with life-enhancing processes, are regarded as part of the welfare services (Rönkkö, 2017). Not only the physical cultural heritage, but also the narratives connected to it, are regarded valuable. It has become more common to document stories and histories connected with old buildings and environments in order to introduce them as living environments with individual and social histories of the places (Aarrevaara \& Rönkkö, 2015).

Within spatial planning, adaptive management of socio-ecological systems necessitates a shift from the traditional 'predict and plan' model to the 'anticipate and adapt' approach (Quay, 2012, 52), and thus, a transition from static and top-down driven spatial planning approaches to more dynamic and anticipatory processes. (Rönkkö et al. 2017). Therefore, strengths-based community planning can be seen as a response to the problem-oriented and rational-comprehensive spatial planning approach. Strengths-based planning can also be regarded as a combination of systematic analysis and creative imagination of designerly thinking, as a synthesis of science and art (see Niiniluoto, 2001). The importance of constructive, and appreciative discussion is highlighted, as aggressive argumentation does not support positive results in communicative processes. What makes this crucial is that if the environment's special character is not recognised and sustained, in the future, the locality will start losing its opportunities to launch other kinds of development strategies based on endogenous factors, comparative advantages and distinctiveness. Yet, building on advantages and strengths may also contain risks. If the strengths-based approach is misunderstood as deliberate manipulation or colonisation of the material and cultural resources, it might ultimately lead to commercial overexploitation, not just regarding natural resources but on history and meanings as well. There are many successful examples in Finland of revitalisation and refurbishment of historic centres and innovative reuse of traditional rural buildings, but unfortunately also some examples of a so-called heritage industry creating built environments with generic and inauthentic structures. The supply of local organic food is another example of comparative advantage in rural localities. Growing demand has increased e.g. the popularity and feasibility of direct farmer-to-consumer marketing. With increasing global demand for organic food, this advantage can similarly be threatened by large-scale organic farming, 'industrial organic', dominating over the locally sourced products (Knox \& Meyer, 2009, 23, 31-32). 
The question of whether the rural localities will thrive or regress in the future depends much on how they respond to the ongoing wave of urbanisation in Finland, and sustain as important nodes of activity after regional government reform comes into effect from 2019 onwards. Echoing Kuhmonen \& Kuhmonen (2015) and the findings from our previous studies on rural localities, it is evident that negative development trajectories and ignorance of the local resources built up a negative "structural inheritance" leading to path dependence, which in the worst case scenario is a self-fulfilling prophecy, as the same strengths, weaknesses, possibilities and threats are repeated for decades. Therefore, it is crucial that rural localities are challenged to creatively think 'outside-the-box' and overcoming the silo- or needs-based view. What is required is the will to create strategic alliances between civil society, business and government, and most importantly, between urban and rural areas. Facilitating a range of partnerships and bringing different resources together could also strengthen the capability of the new regional autonomous bodies and county councils in coordinating collaborative resource management, as well as responding to the societal and environmental challenges presently facing rural regions in Finland.

Academic References

[1] Aarrevaara, E., ed. (2015). Suomalaiset maaseututaajamat 2010-luvulla- tutkimushankkeen loppuraportti [research project]. Lahti: Lahden ammattikorkeakoulu.

[2] Aarrevaara, E. \& Rönkkö, E. (2015). Maaseututaajamien muutosprosessit aluehistorian ja kulttuuriperinnön näkökulmista. Maaseudun uusi aika -verkkolehti. Maaseutututkimuksen ja -politiikan aikakauslehti 23, 5-19.

[3] Auclair, E. \& Fairclough, G., eds. (2015). Theory and Practice in Heritage and Sustainability. Between past and future. New York: Routledge.

[4] Axelsson, R., Angelstam, P., Degerman, E. et al. (2013). Social and Cultural Sustainability: Criteria, Indicators, Verifier Variables for Measurement and Maps for Visualization to Support Planning. AMBIO 42(2), 215-228. DOI: 10.1007/s13280-012-0376-0.

[5] Blomstedt, Y. (1982). Asikkalan historia. Asikkala: Asikkalan kunta.

[6] Campbell, S. (1996). Green Cities, Growing Cities, Just Cities? Urban Planning and the Contradictions of Sustainable Development. Journal of the American Planning Association 62(3), 296-312. DOI: 10.1080/01944369608975696.

[7] Davoudi, S. (2015). Planning as a practice of knowing. Planning Theory 14(3), 1-16. DOI: $10.1177 / 1473095215575919$.

[8] Dopico, E. \& Garcia-Vazquez, E. (2011). Leaving the classroom: a didactic framework for education in environmental sciences. Cultural Studies of Science Education 6, 311-326. DOI: $10.1007 / \mathrm{s} 11422-010-9271-9$.

[9] Elliott, C. (1999). Locating the Energy for Change: An Introduction to Appreciative Inquiry. Winnipeg: International Institute for Sustainable Development.

[10] Hambleton, R. (2014). Leading the Inclusive City. Place-Based Innovation for a Bounded Planet. Bristol: Policy Press.

[11] Ghaye, T., Melander-Wikman, A., Kisare, M., Chambers, P., Bergmark, U., Kostenius, C. \& Lillyman, S. (2008). Participatory and appreciative action and reflection (PAAR) democratizing reflective practices. Reflective Practice 9:4, 361-397. DOI: $10.1080 / 14623940802475827$.

[12] Hawkes, J. (2001). The Fourth Pillar of Sustainability. Culture's Essential Role in Public Planning. Melbourne: Cultural Development Network.

[13] Healey, P. (1997). Collaborative Planning-Shaping Places in Fragmented Societies. London: Macmillan. 
[14] Helminen, V., Tiitu, M., Nurmio, K. \& Ristimäki, M. (2016). Suomen taajamarakenne. Taajamien seututason luokittelu. Suomen ympäristökeskuksen raportteja 32 / 2016, Helsinki: Suomen ympäristökeskus.

[15] Janssens, N. (2008). Designerly thinking \& research. In Hendrick, A., Janssens, N., Martens, S., Nollet, T., Van Den Berghe, J. \& Verbeke, J., eds. Reflections 7 (pp. 203-211). Brussel: Sint-Lucas School of Architecture.

[16] Knox, P. L. \& Mayer, H. (2009). Small Town Sustainability. Economic, Social and Environmental Innovation. Basel, Boston \& Berlin: Birkhäuser.

[17] Kuhmonen, T. \& Kuhmonen, I. (2015). Rural futures in developed economies: The case of Finland. Technological Forecasting \& Social Change 101, 366-374. DOI: 10.1016/j.techfore.2015.07.028.

[18] Kraaijenbrink, J., Spender, JC. \& Groen, A. (2010). The resource based view: A review and assessment of its critiques. Journal of Management 36:1, 349-372. DOI: $10.1177 / 0149206309350775$.

[19] LaGro, J. (2008). Site Analysis. A Contextual Approach to Sustainable Land Planning and Site Design. $2^{\text {nd }}$ Ed. Hoboken: Wiley \& Sons.

[20] Mathie, A. \& Cunningham, G. (2003). From clients to citizens: Asset-based Community Development as a strategy for community-driven development. Development in Practice 13:5, 474-486. DOI: 10.1080/0961452032000125857.

[21] McCammon, S. (2012). Systems of Care as Asset-Building Communities: Implementing Strengths-Based Planning and Positive Youth Development. American Journal of Community Psychology 49, 556-565. DOI: 10.1007/s10464-012-9514-x.

[22] Moseley, M. (2003). Rural development. Principles and practice. London: Sage.

[23] Niiniluoto, I. (2001). Futures studies: science or art? Futures 33(5), 371-377. DOI: 10.1016/S0016-3287(00)00080-X.

[24] Oliver, H. (2014). Exploratory scenario planning. Planning 80(11), 46-47.

[25] Quay, R. (2012). Brave new world of scenario planning. Planning 78(9), 52.

[26] Rittel, H. \& Webber, M. (1973). Dilemmas in a General Theory of Planning. Policy Sciences 4, 155-169. DOI: 10.1007/BF01405730.

[27] Roney, C. W. (2010). Intersections of strategic planning and futures studies: methodological complementarities. Journal of Future Studies 15(2), 71-100.

[28] Rönkkö, E. (2012). Kulttuuriympäristöselvitykset. Tieto, taito ja ymmärrys maaseudun maankäytön suunnittelussa [PhD Dissertation]. Oulu: University of Oulu.

[29] Rönkkö, E. (2015). Maaseudun kirkonkylien ja kulttuuriympäristöjen muutos 1970-luvun lopulta 2010-luvulle. In Aarrevaara, E. ed., Suomalaiset maaseututaajamat 2010-luvullatutkimushankkeen loppuraportti (pp. 20-33). Lahti: Lahden ammattikorkeakoulu.

[30] Rönkkö, E. (2017). Healthy Urban Planning - new approaches for strategic land use planning in the North. In Lankila, T. \& Tervo-Kankare, K., eds., Geographies of well-being in the North (pp. 53-65). Oulu: Nordia Geographical Publications.

[31] Rönkkö, E., Luusua, A., Aarrevaara, E., Herneoja, A. \& Muilu, T. (2017). New Resource-wise planning strategies for Smart urban-rural development in Finland. Systems 5:1, 10. DOI: $10.3390 /$ systems5010010.

[32] Sevaldson, B. (2010). Discussions \& Movements in Design Research. A systems approach to practice research in design. FORMakademisk 3(1), 8-35.

[33] Sneck, T. (1983). Skenaariomenetelmä aluesuunnittelussa. Vaiheittaisen skenaariomenetelmän kehittelyä ja käyttökelpoisuuden tarkastelua. Helsinki: Seutusuunnittelun keskusliitto. 
[34] Soini, K. \& Birkeland, I. (2014). Exploring the scientific discourse on cultural sustainability. Geoforum 51, 213-223. DOI: 10.1016/j.geoforum.2013.12.001.

[35] Soini, K. \& Dessein, J. (2016). Culture-Sustainability Relation: Towards a Conceptual Framework. Sustainability 8(2), 167. DOI: 10.3390/su8020167.

[36] Waylen, KA., Martin-Ortega, J., Blackstock, KL. et al. (2015). Can scenario-planning support community-based natural resource management? Experiences from three countries in Latin America. Ecology and Society 20(4):28. DOI: 10.5751/ES-07926-200428.

\section{Other sources}

[37] Asikkala. 2017. Available at: https://www.asikkala.fi. [accessed 26.1.2017].

[38] Council of the European Union. (2014). Conclusions on cultural heritage as a strategic resource for a sustainable Europe. Education, youth, culture and sport council meeting Brussels, 20 may 2014. Available at:

https://www.consilium.europa.eu/uedocs/cms_data/docs/pressdata/en/educ/142705.pdf [accessed 30.1.2017].

[39] Harava. A survey tool for smart planning. Available at: https://www.eharava.fi/en/ [accessed 30.1.2017].

[40] Hirvonen, S. \& Lohtander, L. (2017). Kansalaisyhteiskunta kulttuuriympäristötyössä. Helsinki: Finnish Local Heritage Federation. Available at: http://www.kotiseutuliitto.fi/julkaisut-ja-tuotteet/kansalaisyhteiskunta-

kulttuuriymparistotyossa [accessed 20.4.2017].

[41] Järvien ja harjun solmukohta. Vääksyn kulttuuriympäristöohjelma - nykytila ja tavoitteet. 2017. Lahti University of Applied Sciences. Unpublished draft.

[42] Land Use and Building Act. (1999). Available at:

http://www.finlex.fi/en/laki/kaannokset/1999/en19990132.pdf_[accessed 26.1.2017].

[43] Ministry of the Environment. (2014). Arviointi maankäyttö - ja rakennuslain toimivuudesta 2013 [Assessment of the effectiveness of the Land Use and Building Act in 2013]. Suomen ympäristö, 1/2014, Helsinki: Ministry of the Environment.

[44] Myllykylä, T. (1991). Suomen kanavien historia. Keuruu.

[45] National Cultural Environment Strategy 2014-2020. Government Resolution 20 March 2014. Helsinki: Ministry of Education and Culture and Ministry of the Environment.

Available at:

https://helda.helsinki.fi/bitstream/handle/10138/135508/Cultural\%20Environment\%20Strate gy_2014.pdf?sequence $=$ [accessed 19.4.2017].

[46] OECD (2017). OECD Territorial Reviews: Northern Sparsely Populated Areas, Paris: OECD Publishing. DOI: http://dx.doi.org/10.1787/9789264268234-en.

[47] Statistics Finland. Vieremä. Available at: http://www.stat.fi/tup/alue/kuntienavainluvut.html\#?year=2016\&active1=925 [accessed 25.1.2017].

[48] Tulonen, A. (1998). Asikkalan kulttuuriympäristöohjelma. Helsinki: Ympäristöministeriö.

[49] UNESCO. (2001). UNESCO universal declaration on cultural diversity. Records of the general conference, 31st session, 15 October - 3 November 2001, Paris, France. Paris: UNESCO.

[50] Valtakunnallisesti arvokas rakennettu ympäristö, RKY. [Nationally Valuable Built Environment, RKY]. Available at:

http://www.rky.fi/read/asp/r_kohde_det.aspx?KOHDE_ID=1895 [accessed 26.1.2017]. 
[51] Vanha Vääksy. [Old Vääksy]. Available at: http://vanhavaaksy.fi/?page_id=829 [accessed 27.1.2017].

[52] Wager, H. (2006). Päijät-Hämeen rakennettu kulttuuriympäristö. Lahti: Päijät-Hämeen liitto.

[53] WCCD (1995). Our Creative Diversity. France: EGOPRIM.

[54] Vääksyn vesimyllymuseon naapuriin kerrostalo. Yle Online News 20.7.2010. Available at: http://yle.fi/uutiset/3-5599639 [accessed 27.1.2017].

[55] Wilenius, M. (2015). Pieni tulevaisuuskirja. Helsinki: Otava. 